\title{
THE DEVELOPMENT OF THE UNDERSTANDING OF ARRHYTHMIAS DURING THE LAST 100 YEARS
}

\author{
by
}

\section{DENNIS M. KRIKLER*}

More than 100 years ago, the physiologist Rudolf Heidenhain used the term "arrhythmia" as a one-word description for disturbances of cardiac rhythm. ${ }^{1}$ It was soon adopted by French authors, notably Germain Sée. ${ }^{2}$ The later coinage, "dysrhythmia", has often been used by its protagonists as synonymous with arrhythmia, ${ }^{3}$ which today embraces changes in both rate and rhythm. Before graphic methods were invented, the assessment of changes in the heart's rate and rhythm was based on tactile examination of the pulse, with the result that, in most cases, only overall descriptive terms were employed. Although the advent of graphic techniques meant that these disorders could be defined by location or site of initiation, it was after naked-eye observations of the isolated animal heart that Theodor Engelmann used the word "extrasystole".4,5 When graphic techniques were first introduced, they were not immediately applied to the study of arrhythmias. Sphygmography, for example, the simplest of these techniques, could have been used to differentiate between tachycardias, but instead it was employed to gain information about the state of the heart's valves. ${ }^{6}$

Abnormalities of rate have long been recognized clinically. In 1875, Thomas Lauder Brunton ${ }^{7}$ described how chloroform anaesthesia in some patients produced a rapid heart rate, shock, and even death. This observation was later reproduced experimentally when Goodman Levy and Thomas Lewis demonstrated that ventricular tachycardias and fibrillation could be induced by chloroform. ${ }^{8}$ According to Martius, it was Bressler who first used the term paroxysmal tachycardia, in the

*D. M. Krikler, MD, FRCP, Royal Postgraduate Medical School, Hammersmith Hospital, Ducane Road, London W12 OHS.

\footnotetext{
${ }^{1}$ R. Heidenhain, 'Über arhythmische Herzthätigkeit', Pflügers Arch. ges. Physiol., 1872, 5: 143-153.

2 G. Sée, Traité des maladies du coeur, étiologique et clinique, Paris, Lecroisnier et Babé, 1889, vol. 1, pp. 516-526.

${ }^{3}$ D. Krikler, 'What to call arrhythmias?', Br. Heart J., 1978, 40: 1325-1326.

4 T.W. Engelmann, 'Beobachtungen und Versuche am suspendirten Herzen. Zweite Abhandlung. Über die Leitung der Bewegungsreize im Herzen', Pflügers Arch. ges. Physiol., 1894, 56: 149-202.

${ }^{5}$ C. Fisch, 'Aberration: seventy-five years after Sir Thomas Lewis', Br. Heart J., 1983, 50: 297-302.

- T. Lorain, Etudes de médecine cliniques faites avec l'aide de la méthode graphique et des appareils enregistreurs. La pouls, ses variations et ses formes diverses dans les maladies, Paris, J.B. Baillière, 1870.

${ }^{7} \mathrm{~L}$. Brunton, One of the causes of death during the extraction of teeth under chloroform. Collected papers on circulation and respiration, London, Macmillan, 1907, pp. 427-437.

${ }^{8}$ A.G. Levy and T. Lewis, 'Heart irregularities, resulting from the inhalation of low percentages of chloroform vapour and their relationship to ventricular fibrillation', Heart, 1911-12, 3: 99-112.
} 


\section{M. Krikler}

New York Medical Record of January $1889 .{ }^{9}$ It was also used by Hoffmann in a monograph of $1900 . .^{10} \mathrm{Karl}$ Wenckebach, in his book on arrhythmias published in 1903, referred to the disorder as a single phenomenon. ${ }^{11}$ A decade later, his text distinguished ventricular tachycardia from the atrial and junctional forms. ${ }^{12}$ In 1908 , James Mackenzie followed Hoffmann's usage in describing cases of paroxysmal tachycardia in his Diseases of the heart. ${ }^{13} \mathrm{He}$ included under this term patients having both regular and irregular rhythm, and he did not distinguish the site of impulse formation.

A seminal development in making the distinction between arrhythmias easier was the introduction of a practical form of electrocardiograph. The capillary electrometer method, developed by Augustus Waller, was an important forerunner of the modern technique devised by Willem Einthoven. ${ }^{14}$ The basis of this was an improved string galvanometer-a invention for which Einthoven received the Nobel prize. ${ }^{15}$ But it was largely through the work of Thomas Lewis that electrocardiography was introduced into clinical practice. From an extensive series of observations gathered over a period of ten years, he and his colleagues defined most of the arrhythmias. ${ }^{16}$ In the final and definitive third edition of his book on arrhythmias, published in 1924, he identified and analysed the arrhythmias in terms that we still use. ${ }^{17}$ The sole exception is what today is called pre-excitation, but even this disorder can, with hindsight, be recognized in two references included in his monumental bibliogaphy. ${ }^{18,19}$

Pre-excitation, or Wolff-Parkinson-White syndrome, was first described as a clinical entity and defined by electrocardiography in $1930 .^{20}$ It is a congenital disorder giving rise to paroxysmal tachycardia and, electrocardiographically, it features a short PR interval and a wide QRS syndrome. The account of this disorder resulted from a comparison of tracings by the English cardiologist John Parkinson and the American physician Paul White, made when White was visiting London. Other workers soon appreciated that cases of paroxysmal tachycardia, which had been described as early as $1915^{19}$, fell into the same category. In 1914, G.R. Mines ${ }^{21}$

\footnotetext{
${ }^{9}$ F. Martius, Tachycardie. Eine klinische Studie, Stuttgart, Ferdinand Enke, 1895.

${ }^{10}$ A. Hoffmann, Die paroxysmale Tachycardie. Anfälle von Herzjagen, Wiesbaden, Bergmann, 1900.

${ }^{11}$ K.F. Wenckebach, Die Arhythmie als Ausdruck bestimmter Funktionsstörungen des Herzens. Eine physiologische-klinische Studie, Leipzig, Wilhelm Engelmann, 1903.

${ }^{12}$ K.F. Wenckebach, Die unregelmässige Herztätigkeit und ihre klinische Bedeutung, Leipzig, Wilhelm Engelmann, 1914.

${ }^{13} \mathrm{~J}$. Mackenzie, Diseases of the heart, London, Henry Frowde, 1908.

14 W. Einthoven, 'The string galvanometer and the human electrocardiogram', K. Akad. Wet. Amst., Proc. Sect. Sci., 1903-4 6: 107-115.

${ }^{15} \mathrm{~W}$. Einthoven (Nobel Lecture, 1925), 'The string galvanometer and the measurement of the action currents of the heart', Nobel Lectures: Physiology or Medicine, 1922-41, Amsterdam, Elsevier, 1965, pp. 94-111.

${ }^{16} \mathrm{~T}$. Lewis, The mechanism of the heart beat, London, Shaw, 1911.

${ }_{17} \mathrm{~T}$. Lewis, The mechanism and graphic registration of the heart beat, 3rd ed., London, Shaw, 1924.

${ }^{18}$ A.E. Cohn and F.R. Fraser, 'Paroxysmal tachycardia and the effect of stimulation of the vagus nerves by pressure', Heart, 1913-14, 4: 93-105.

${ }^{19}$ F.N. Wilson, 'A case in which the vagus influenced the form of the ventricular complex of the electrocardiogram', Arch. intern. Med., 1915, 16: 1008-1027.

${ }^{20}$ L. Wolff, J. Parkinson, and P.D. White, 'Bundle-branch block with short P-R interval in healthy young people prone to paroxysmal tachycardia', Am. Heart J., 1930, 5: 685-704.
} 


\section{The development of the understanding of arrhythmias}

had postulated the occurrence of reciprocating atrioventricular tachycardia involving the atrioventricular node and an accessory pathway; an extremely far-sighted interpretation, in physiological terms, of a recent anatomical description. Recently, an even earlier case has been recognized in a description by Fraser and $\mathrm{Cohn}^{22}$ (see below).

In all this work there can be no doubt of the fundamental importance of Lewis, whose position was central in the development of electrocardiography as a clinical tool and as a research instrument, particularly for investigating disorders of rhythm and conduction. ${ }^{23}$ But why did Lewis work on cardiology and why the arrhythmias in particular? Clearly, it was important that he worked at University College Hospital, London, for at that time there were others there also interested in the new approach to the heart. Sydney Ringer, who had developed the technique for perfusing the frog's heart, had worked there for many years. In 1905, Arthur Cushny returned from the United States to take up the new chair of pharmacology. Amongst other things, Cushny worked on the experimental production of arrhythmias. In 1899, Ernest Starling transferred from the chair of physiology at Guy's Hospital to that at University College. ${ }^{24}$ Another influence, on a much less well-known level, may have been that exerted by Alfred Goodman Levy ${ }^{25}$ Levy, after qualifying from University College Hospital in 1892, spent four years in Matabeleland and then returned to London where, among other activities, he undertook research in the laboratories of University College Hospital, devising a "regulating chloroform inhaler" designed to make this anaesthetic agent safe. Lewis, who had just graduated, may have been exposed to this particular concern of Levy's at a critical time in his own intellectual career.

A major arrhythmia that Lewis characterized at an early stage in his work was atrial fibrillation. ${ }^{26}$ It is clear that fibrillation had been observed by Harvey during his initial experiments; it was also known to Sénac and Laennec. The irregular pulse, however, remained the object of many theories in the first decade of the present century. ${ }^{27}$ In 1903, H.E. Hering postulated that the atria were inactive in this condition. ${ }^{28}$ So did Mackenzie, who recorded the irregular ventricular rhythm in this disorder with his polygraph, and attributed its origin to the atrioventricular node. ${ }^{29}$ Once the electrocardiograph was used to investigate the condition, disagreement was resolved remarkably quickly. Lewis showed that the clinical condition of total

\footnotetext{
${ }^{21}$ G.R. Mines, 'On circulating excitation in heart muscles and their possible relationship to tachycardia and fibrillation', Proc. Trans. R. Soc. Can., 3rd ser., 1914, 8 (sect. 4): 43-52.

${ }^{22}$ D.M. Krikler, 'Wolff-Parkinson-White syndrome: long follow-up and an Anglo-American historical note', J. Am. Coll. Cardiol., 1983, 2: 1216-1218.

${ }^{23}$ A. Hollman, 'Thomas Lewis-the early years', Br. Heart J., 1981, 46: 233-245.

24 W.B. Fye, 'Ernest Henry Starling, his law and its growing significance in the practice of medicine', Circulation, 1983, 68: 1145-1148.

${ }^{25}$ D.M. Krikler, 'Alfred Goodman Levy-Bulawayo's first doctor', Centr. Afr. J. Med., 1969, 15: 97-99.

${ }^{26} \mathrm{~T}$. Lewis, 'Auricular fibrillation and its relationship to clinical irregularity of the heart', Heart, 1909-10, 1: 306-372.

${ }^{27}$ J. McMichael, 'History of atrial fibrillation 1628-1819. Harvey-de Sénac-Laennec', Br. Heart J., 1982, 48: 193-197.

${ }^{28}$ H.E. Hering, 'Analyse des Pulsus irregularis perpetuus', Prag. Med. Wschr., 1903, 28: $377-381$.

29 J. McMichael, 'Sir James Mackenzie and atrial fibrillation. A new perspective', J.R. Coll. Gen. Practnrs, 1981, 31: 402-406.
} 


\section{M. Krikler}

irregularity of the pulse was associated electrocardiographically with totally irregular atrial contraction and that this was the same as the condition of fibrillation which others, notably Cushny, had produced experimentally in animals. ${ }^{30}$ Simultaneously and independently of Lewis, two workers in Vienna, Carl J. Rothberger and Heinrich Winterberg, unravelled this disorder. ${ }^{31}$

Lewis's publications, which showed how arrhythmias yielded much of their mystery when electrocardiographic analysis was properly performed and the tracings carefully interpreted, soon had an impact on the wider world. The number of American cardiologists who came to study with Lewis before 1914 illustrates this point. Many more came over with the American forces during the war, resulting in his influence being even more widely disseminated. Among the very earliest of the American visitors was Alfred Einstein Cohn (1897-1957). Cohn spent two years in Europe after graduating from Columbia University, and the very last part of his stay was with Lewis in 1909 at University College Hospital. Cohn brought the first string galvanometer to the United States ${ }^{32}$ when he joined the staff of the Rockefeller Institute for Medical Research in 1911. His influence on his trainees was considerable. Several senior American cardiologists still have warm personal memories of Cohn, who, after his early cardiological researches, had a distinguished career in clinical practice. Early electrocardiographs were cumbersome and tracings were recorded with limbs immersed in buckets of saline. Cohn introduced a "strap-on" electrode in 1920, which, at once, enhanced the mobility of electrocardiography. ${ }^{33}$

In fact, before the Great War, intellectual currents also flowed in the opposite direction, and a few young European physicians were spending time on postgraduate work in the United States. One of the foremost, as judged by his subsequent career, was Francis R. Fraser (1885-1960). Although he is best remembered for his work on respiratory disease, pernicious anaemia, and diseases of the thyroid, much of his early work in the United States was on digitalis and was carried out with Cohn. A key paper on paroxysmal tachycardia and vagal stimulation was written by the two of them. ${ }^{34}$ For a time, this paper was forgotten, but it is now clear that they had, albeit without appreciating the significance of their observations, described the first patient suffering from paroxysmal supraventricular tachycardia complicating pre-excitation. Upon his return to England with the Harvard Medical Unit, Fraser worked at the Hampstead Hospital with F.N. Wilson and Thomas Lewis. Together with Wilson, he tested the effects of intravenous adrenaline and apocodeine in patients with "disordered action of the heart" and found that they reacted more strongly to

${ }^{30}$ Lewis, op. cit., note 26 above.

${ }^{31}$ C.J. Rothberger and H. Winterberg, 'Vorhofflimmern und Arhythmia perpetua', Wien. klin. Wschr., 1909, 22: 839-844.

${ }^{32}$ G.E. Burch and N.P. DePasquale, $A$ history of electrocardiography, Chicago, Year Book Medical, 1964, pp. 86-88.

${ }^{33}$ S.L. Barron, 'The development of the electrocardiograph in Great Britain', Br. med. J., 1950, i: 720-725.

34 Cohn and Fraser, op. cit., note 18 above.

${ }^{35}$ F.R. Fraser and F.N. Wilson, in Report upon soldiers returned as cases of "disordered action of the heart" (DAH) or "valvular disease of the heart" (VDH), Medical Research Committee, Report No. 8 London, HMSO, 1917, pp. 30-31. 


\section{The development of the understanding of arrhythmias}

adrenaline than did controls. While apocodeine seemed to have beneficial effects, these were deemed insufficient to warrant its further employment. ${ }^{35}$

As Lewis transferred his attention away from the heart after the completion of the third edition of his book in $1924^{36}$ it is to Wilson and his colleagues that one has to turn to see the development of electrocardiography. The United States in the 1920s and '30s saw the establishment of a new school of American cardiologists who rose to the forefront of the field. The school was later enriched by continental workers, many of whom joined American physicians when forced to leave Europe in the 1930s and '40s. This was particularly true of Chicago, where a number of European emigrées including Richard Langendorf and Alfred Pick worked under the leadership of Louis N. Katz. Indeed, until the advent of practical intracardiac electrocardiography in 1969 , it was the American school that produced the major advances in the understanding of arrhythmias.

It is said that Lewis felt that the electrocardiograph had yielded all it could about arrhythmias by 1924 or thereabouts. Some might say that the same now applies to intracardiac electrography, but this remains to be seen, and I much doubt it. It was Werner Forssmann who initiated this technique when he catheterized his own heart in 1929. Forssmann, along with Wilhelm His, believed that the technique could not produce signals from which activity of the bundle of His could be interpreted.$^{37}$ But, during the Second World War, deprived of all knowledge of developments in the United States and Great Britain, Lenègre and Maurice ${ }^{38}$ undertook cardiac catheterization and reported the recording of intracardiac signals. In spite of Puech's demonstration of its potential clinical value, ${ }^{39}$ technical difficulties prevented the further immediate implementation of this method of cardiac investigation. Once Scherlag and his colleagues had designed proper filters and made reproducible intracardiac electrograms available, ${ }^{40}$ the way was open to make such recordings clinically. With the introduction of programmed electric stimulation of the heart, ${ }^{41}$ concepts like automaticity and re-entry could be tested, diagnoses confirmed or changed, and therapeutic possibilities explored.

A century has witnessed the move from the investigation of arrhythmias by palpation of the pulse and the use of mechanical traces to electrical recording from both the surface of the body and cavity of the heart. Hand in hand with this have gone changing treatments for arrhythmias, including new drugs, electrical pacing, defibrillation, and surgery. Each of these stages has been punctuated quite clearly by the personal roles of many physicians and surgeons. But the ways in which their work could be fruitfully employed were not always fully recognized at the time.

\footnotetext{
${ }^{36}$ Lewis, op. cit., note 17 above.

${ }^{37}$ W. Forssmann, Experiments on myself. Memoirs of a surgeon in Germany, London, St James Press, 1974 , p. 87.

${ }^{38} \mathrm{~J}$. Lenègre and $\mathrm{P}$. Maurice, 'De quelques résultats obtenus par la dérivation directe intracavitaire des courants électriques de l'oreillette et du ventricule droits', Arch. Mal. Coeur, 1945, 37-38: 298-302.

${ }^{39} \mathrm{H}$. Latour and P. Puech, Electrocardiographie endocavitaire, Paris, Masson, 1957.

${ }^{40}$ B.J. Scherlag, S.H. Lau, R.H. Helfant, W.D. Berkowitz, E. Stein, and A.N. Damato, 'Catheter technique for recording His bundle activity in man', Circulation, 1969, 39: 13-20.

${ }^{41} \mathrm{D}$. Durrer, 'Electrical aspects of human cardiac activity: a clinical physiological approach to excitation and stimulation', Cardiovasc. Res., 1968, 2: 1-8.
} 